\title{
Does Smoking and Alcohol Abuse Precipitate and Aggravate the Risk of Metabolic Syndrome?
}

\section{María Eugenia Velasco-Contreras Grado*}

Unit of Primary Attention of Health, Coordination of Comprehensive Health Care for the First Level of Care; Division of Information and Medical Support, Mexican Institute of Social Security, Mexico

\begin{abstract}
Objective: To know what is the degree of association between the presence of vascular complications in people with obesity, diabetes, hypertension and the different degree of consumption of tobacco or alcohol.

Methods: From March to December 2009 were 20,000 surveys to health workers and other occupational categories randomly selected in the 35 delegations of the IMSS, in each State. The study of variables included: affiliation, sex, age, job category, and registration of known diseases, smoking, nicotine addiction, and consumption of alcohol risk, addiction to alcohol, habits, physical exercise and eating habits. Analysis statistical, was held in the SPSS version 17 system, was obtained frequencies, point prevalence of the risk factors, smoking, prevalence of chronic diseases and Terminal vascular complications, chronic pulmonary damage, (COPD) liver cirrhosis and neoplasm's (cancer unspecified organ. Analysis bivariate estimate of the relative risk of Association of risk factors and addictions with obesity, and with chronic diseases and complications terminals, by estimating the right odds to the prevalence, $\mathrm{Cl}=$ confidence interval; Chi-square of Mantel-Haenszel (Xmh)
\end{abstract}

Results: The consumption of more than five cigarettes per day in women associated with obesity RMP 1.43 IC (1.03-1.98) Xmh 2.1 and abusive consumption of alcohol is associated with obesity in men with 1.81 RMP IC (1.57-2.10) Xmh 8.0

With respect to vascular complications in women who smoke at least one cigarette a day's Association was found with cerebral vascular disease (EVC) 3.24 RMP IC (1.58-6.66) Xmh 3.38, with RMP cardiac infarct of 2.69 IC (1.66-4.38) Xmh 4.16; Women in large smokers for more than 5 cigarettes a day Association was found with EVC RMP 4.50 Cl (1.37-14.8) Xmh 2.71; with infarct heart $3.07 \mathrm{IC}$ (1.23-7.65) Xmh 2.53, diabetes, RMP $1.61 \mathrm{IC}(1.05-2.46)$ Xmh 6.82 hypertension RMP 1.21 IC (1.001.74) Xmh 3.05 and Dyslipidemia RMP 1.22 IC (1.00-2.04) Xmh 2.29

Men in heavy smokers Association was established as follows: EVC, RMP 2.69 IC (2.22-14.61) Xmh 4.08; Cardiac infarct, RMP 2.68 IC (1.51 - 4.76) Xmh 3.48; diabetes, RMP 1.63 IC (1.20-2.20) Xmh 7.13; Hypertension, RMP $1.30 \mathrm{Cl}(1.00-1.69)$ $\mathrm{Xmh} 4.31$.

With regard to the abusive consumption of alcohol in women Association was found with EVC, RMP 2.40 IC (1.08 - 5.31) Xmh 2.22 .

In men with alcohol addiction Association was found to EVC, RMP 7.15 IC (1.65 - 31.01) Xmh 3.07, cardiac infarction, RMP 3.21 IC (1.16-8.92) Xmh 2.36, diabetes, RMP 1.96 IC (1.11-3.46) Xmh 2.35; arterial hypertension, RMP 1.75 IC (1.07-2.87) Xmh 2.26

In women with alcohol addiction Association was found to RMP 25.82 IC (7.46-98.40) cardiac infarct Xmh 7.68, diabetes, RMP 4.69 IC (1.71-12.80) Xmh 3.31; arterial hypertension, RMP 2.99 IC (1.17-7.66) Xmh 2.40

In hypertensive patients with more than 5 cigarettes a day smoking Association was found with EVC, RMP 85.6 IC (40.1182.9) Xmh 12.6; Cardiac infarct, RMP 2.88 IC (2.50-3.33) Xmh 10.5. In hypertensive patients with alcohol addiction Association was found with EVC, RMP 45.9 IC (23.7-88.9) Xmh 9.13; Cardiac infarct, RMP 37.7 IC (22.5-62.1) Xmh 12.8. In large smoking diabetic patients Association was found with EVC, RMP 97.8 IC (36.4-262.5) Xmh 11.0, with RMP 50.8 IC (26.5-97.2) cardiac infarct Xmh 13.1. In diabetic patients with addiction alcohol Association was found with EVC, RMP 35.9 IC (15.1-85.4) Xmh 5.4, with cardiac infarct, RMP 26.9 IC (14.6-49.7) Xmh 8.1

Conclusions: The metabolic syndrome is identified clinically by obesity, associated with hypertension, diabetes mellitus and Dyslipidemia. This increases the risk of vascular complications even before having identified chronic diseases, diabetes and hypertension. In this study associated with vascular damage in women who smoke at least one cigarette in the day, both of EVC, and cardiac infarction. The increase of the Association is not much larger with more than 5 smoking a day, suggesting greater vascular lability in women who smoke without serious nicotine addiction. Analyze the Association of smoking of cigarettes more than 5 a day with other components of the metabolic syndrome is identified to increase the presence of diabetes 1.61 times higher in women and 1.63 in men, when compared with non-smokers, Increases 1.21-1.30 and women hypertension and 1.22 single dyslipidaemia in women. With respect to vascular complications, large men smoking their increase is one and a half times less than in women, but 2 and half times higher than in men non-smoking.

In hypertensive and diabetic heavy smokers compared patient's non-smoking increases by 85 and 100 times the risk of EVC respectively: for myocardial infarction 3-50 times more respectively. This suggests a clear difference in the coronary vascular damage generated by diabetes to hypertension.

In men, the abusive consumption of alcohol was clearly associated to obesity. In women compared with abstemias women the EVC associated with 2 and a half times more.

Addiction to alcohol in men increased 7 times more the presence of EVC. In men and women cardiac infarct, 3 and 25 times more, diabetes mellitus 2 and 5 and arterial hypertension 2 and 3 respectively when compared with abstainers men and women.

In hypertensive and diabetic patients with alcohol addiction Association was found with EVC 46 and 36 times more risk, to cardiac infarct almost 40 and 27 times more risk when compared with hypertensive and diabetic abstainers. 
Keywords: Alcohol precipitate; Tobacco; Metabolic syndrome

\section{Introduction}

In recent decades non-communicable chronic diseases have become an epidemic, associated with unhealthy lifestyles. The set of diseases is integrated by increase of body fat in subcutaneous tissue and accumulate fat ectopic in internal organs: liver, pancreas, heart, muscles and probably kidney. Manifested by Overweight/obesity, steatosis liver, followed by high blood pressure, type 2 diabetes, dyslipidemias, cerebrovascular, renal, coronary disease, complicated by the epidemic of tobacco use and alcohol consumption give rise to chronic obstructive pulmonary disease, cirrhosis of the liver, and some types of cancer [16]. All give rise to major causes of disease, disability and premature death, which bring together the high cost for health, treatment and rehabilitation services [7-11]. The factors of risk more prevalent and with greater negative impact on global health is a lifestyle consisting of bad habits of nutrition, sedentary lifestyle, smoking and abusive consumption of alcohol [12] there is a body of information indicating that they are associated or generate metabolic syndrome; consisting of sobrepeso-obesidad, hypertension, hepatic steatosis, pre-diabetes, type 2 diabetes mellitus, Dyslipidemia; which explains, the global increase in morbidity and cardiovascular mortality, cancer, chronic lung damage, cirrhosis of the liver, and terminal kidney damage [7,8]. Sedentary; in 1994 who recognized it as an independent risk for diabetes mellitus type 2, osteoporosis, ischemic heart disease factor and estimated that by itself alone, double the risk of becoming ill or dying, compared with people who perform daily physical exercise $[13,14]$. Smoking- Who defined as a disease and public health of global magnitude problem; in 2006 reported that they died a day 14,500 people and 6 million a year from related diseases [15]. In developed countries causes $15 \%$ of total health care costs. In United States the annual cost of treatment of diseases attributable to tobacco is $\$ 50$ billion dollars, with 47 billion losses in wages and productivity $[10,11]$ disease control (CDC) defines to smoking, such as the consumption of at least 100 cigarettes during life and smoking at the present time. It is a disease that starts as a habit during adolescence and causes nicotine addiction in adults with physical and psychological dependence, difficult-to-treat for the suspension of smoking; due to the massive increase of Nicotinic Receptors in the central nervous system [16]. The national survey of 2007 addiction (ENA/2007), reported $26.4 \%$ of smokers and $25.6 \%$ of liabilities [17]. In health professionals smoking is higher than in the general population. In Mexico, the figures vary between $14 \%$ to $31 \%$, depending on the institution, geographic area and population studied [18]. Smokers have more health problems, use more medical services, less physical exercise and have more depression. Has it been established according to the study of the global tobacco epidemic carried out by the whom that $50 \%$ of them have death before age 35 . In relation to mortality: lung cancer is attributed $79 \%$, obstructive pulmonary disease chronic myocardial infarction $78 \%$ to $48 \%$ and Cerebral Vascular disease $38 \%$. In relation to the consumption of drinks with alcohol who defines alcoholism as a chronic disease characterized by disorders behavioral, mental and physical caused by compulsive consumption of alcoholic beverages. Addiction to alcohol is manifested by tolerance, dependence and withdrawal syndrome; with involvement of social, family, work and school life [19]. It is one of the main causes of the global burden of disease and disability. Its relationship with chronic diseases is clear since dependency, is associated with the chronic lack of control of hypertension, diabetes, has you been linked recently to cardiac infarct in cerebral vascular disease in men and women [19]. generates relatively long-term liver cirrhosis due to toxicity to the newspaper excessive consumption, and other individual the health damage, such as physical injury from acute poisoning, death by accident of traffic, violence, homicides, suicides, family, generation of children and adolescents with chronic depression and high risk of alcoholism in adulthood [20] the official Mexican standard defines Overweight / obesity as a chronic disease accompanied by metabolic disturbances and deterioration in the State of health [21]. The prevalence of Overweight/obesity has increased in recent decades and is considered a pandemic for its contribution to the burden of disease. WHO estimates that there are 300 million obese worldwide, adding those who have overweighted the figure rises to 1000 million. In the last 20 years studies, have been conducted to define that obesity is always preceded by the overweight, that is not obesity, but neither is normal weight. Metabolic abnormality parameters increase exponentially to the extent of the subject moves away from its normal weight [22-26]. Much of its causality is considered by global increase in consumption of foods low in nutrients and very high in simple sugars, refined flour mixed with vegetable fats saturated, with reduction to zero consumption of fruits/ vegetables and severe physical inactivity [27]. The obesity generates and is associated in most cases hypertension, glucose intolerance, diabetes type 2, coronary artery disease, lung disease, sleep apnoea sleep, joint diseases, vesicular diseases and several types of cancer. It is responsible for $40 \%$ of endometrial cancer, $25 \%$ of renal cancer and $10 \%$ of colon and breast cancers [28]. According to reports from several controlled studies published in the last decade changes in the habits of power through counseling can promote weight loss of 5 to 20 pounds in a year [27]. As primary treatment recommended the modification of behavior and ways of life in the way of eating and physical activity of moderate to intense daily minimum for 30 minutes [29]. In very small part have been studied the factors and determinants of chronic diseases that are part of the metabolic syndrome, with measuring isolated smoking and alcoholism no comprehensive assessment of the State of global health, and increased risk of morbidity and mortality for vascular complications such as cerebral vascular disease manifested as accident and aftermath, as well as a history of cardiac infarction myocardial infarction. We do not know if there is Association and as it increases the risk of vascular damage in obese patients with high probability of studying with metabolic syndrome with sedentary lifestyle, practice physical exercise of protection of health, with the consumption of legal drugs of high prevalence of global consumption such as tobacco and alcohol

The objective of this study is to know the prevalence of risk factors for the inappropriate eating habits in lifestyle, practice of physical exercise, use of legal drugs and his relationship with the presence of chronic diseases: obesity, hypertension, diabetes mellitus, Dyslipidemia, and its vascular complications: infarction cardiac, cerebral vascular disease or degenerative complications such as cancer, chronic obstructive pulmonary disease, and cirrhosis of the liver in health workers, compared with other job categories of the IMSS.

*Corresponding author: María Eugenia Velasco-Contreras Grado, Division of Information and Medical Support, Mexican Institute of Social Security, Insurgentes Sur 253, 5th floor. Colonia Roma Sur, delegation Cuauhtémoc, CP 06700, Mexico, Tel: 551478 79; Fax: 551478 78; E-mail: maria.velasco@imss.gob.mx

Received April 02, 2014; Accepted April 26, 2014; Published May 03, 2014

Citation: Velasco-Contreras Grado ME (2014) Does Smoking and Alcohol Abuse Precipitate and Aggravate the Risk of Metabolic Syndrome? J Metabolic Synd 3 141. doi:10.4172/2167-0943.1000141

Copyright: (C) 2014 Velasco-Contreras Grado ME. This is an open-access article distributed under the terms of the Creative Commons Attribution License, which permits unrestricted use, distribution, and reproduction in any medium, provided the original author and source are credited. 


\section{Methods}

\section{Study design}

From March to December 2009 20,000 surveys were applied in the 35 delegations of the IMSS, in a sample of workers in ordinary regime, all labor categories, attached to the buildings that make up the infrastructure and organization of the Institute, State delegations and in the Federal District. A representative sample of the whole of the IMSS workers of all categories of both shifts according to the existing template was calculated at December 2008. $(397,906)$, they were invited to participate through verbal consent, with anonymous registration of the survey. Sample was weighted by delegation and labor category, in the areas of administrative, social and medical benefits. The procedure for the selection, were allocated according to the proportion of each delegation IMSS.

\section{Category}

Health workers, Administrative and quartermaster of the total delegation sample.

\section{Selection criteria}

Workers of all labor categories who agree to participate. Exclusion criteria: what the worker does not accept participation criteria of elimination: surveys without registration of more than $50 \%$ of the requested data. The study of variables included: delegation, sex, marital status, age, work shift, service, job category, seniority, schooling, somatometría: current weight in kilos, height in $\mathrm{cm}$, waist in $\mathrm{cm}$, systolic, diastolic blood pressure, glucose, uric acid, hemoglobin, cholesterol, triglycerides, LDL, DHL, hereditary risk history, registration of known diseases, years of suffering from the disease, in the last year: number of consultations received, days of hospitalization, number of days of incapacity. Smoking away, this, exfumador, number of cigarettes per day, the addiction to nicotine, (Fagerstrom) assessment. Evaluation of the consumption of alcoholic beverages, abstemio, and risk alcohol consumption: responded in the affirmative that it has consumed in the last year more than 3 glasses, in less than 3 hours or more than 3 times.

\section{Alcohol addiction}

- Tolerance: You had the need to drink more to achieve the same effect.

- Unit 1: when you drink alcohol, ends up drinking more than what was initially planned.

- Unit 2: has tried to reduce the drinking quantity or stop drinking, but failed.

- Unit 3: in the days of baby, spends a number of considerable time to obtain alcohol or drink to recover from its effects.

- Unit 4: invest less time in work, enjoy a hobby, or be with others because of his fondness for drink.

- Alcohol withdrawal syndrome: when you stop drinking their hands tremble, sweat or feel restless and also drink to avoid these symptoms.

\section{Pattern of physical exercise}

Characteristics of the type of practiced physical exercise: frequency to the week, duration session and intensity. Indicator: 1) physical exercise practiced for 30 minutes or most days of the week. 2) Insufficient physical exercise 3) physical inactivity or sedentary lifestyle.

\section{Eating pattern}

Customary practice of an individual using a set of products in 3 sessions each day in order to meet the requirements of your body indicator: 1) pattern of habits and consumption of healthy food 2) pattern of inadequate food habits and consumption of unhealthy foods. Type of food it consumes, frequency per week and number of servings per occasion. Habits: add salt and sugar to your food, you make 3 meals a day, consume daily fruit and eat vegetables daily. Registration of diseases: condition of health given by chronic degenerative diseases and their complications: obesity, diabetes mellitus, arterial hypertension, cardiac infarct, cerebral vascular disease, obstructive pulmonary disease chronic (COPD), cancer, cirrhosis of the liver. Known by the worker as a result of medical care received as a diagnosis, treatment, regular consultations, hospitalization, disabilities and time evolution of the disease.

A questionnaire Likert-type and items with dichotomous choices, 78 questions, with 11 subscales were used: 1.-social and demographic; 2 Somatometría; 3. hereditary antecedents of risk; 4. pathologic personal antecedents; 5 . disabilities; 6 . tobacco use; 7. evaluation of the nicotine addiction; 8 . evaluation of the consumption of alcoholic beverages; 9 . detection of diseases; 10 . Physical activity pattern; 11. Eating pattern. The instrument shows consistency or homogeneity, with an alpha of Cronbach 0.80 . Surveys were sent to each delegation in number and distribution of categories of workers who should survey based on the number of workers by delegation in each category. With a responsible for performing distribution according to the guidelines for its application and invite the workers of randomly selected units of the delegation. Be informed directors of the units of the purpose of the survey, selection and training of personnel responsible for applying it. Workers who agreed to participate were cited in a classroom, Auditorium and multi-purpose room to record the survey in a single moment. The delegation head, sent surveys requested the coordination of integrated programs of health, the public health unit. They were validated for their capture in the optical reader system, responsible for the system developed reading template. It was cleaned and validated the database for processing and analysis.

\section{Statistical analysis}

Performed in the SPSS version 17 systems, the frequencies obtained is point prevalence of the risk factors, smoking, prevalence of chronic and Terminal vascular complications, chronic lung damage, liver cirrhosis and neoplasm's diseases. In analysis bivariate estimation the relative Association of risk factors, addictions with obesity, and those with chronic diseases and complications terminals.

Ethical aspects based on the regulation of the General Law of health in research in health, in the title 1 , article 17 and category 1 is considered to this type of research as of minimal risk, minimal time investment, depends on truthful worker participation because it is an anonymous survey. The design is in keeping with the principles of the Declaration of Helsinki I, 1964, Declaration of Helsinki II, 1975, Tokyo, 1983 in Venice, 1989 Hong Kong. To ensure the confidentiality of the data of the study population, their right not to participate if it was not their will, when requesting consent was upheld, did not register his name and explained to his knowledge and clarity of the ethical aspects of the study, its purpose and further processing of the data collected. 


\section{Results}

Sent 25000 surveys with response rate of $79.5 \%$, a total of 19,532 surveys were analyzed.

(Table 1) (Figure 1).

Sedentary lifestyle affects more than $85 \%$ of respondents, the highest prevalence is women in general with more than $90 \%$, and the highest number was found in the men in the delegation from Zacatecas with $97 \%$.

The consumption of foods with excess calories, junk, fast food and sweet bread in general affects $40 \%$ of the respondent.

With respect to the unhealthy habits like having fasting, not eat fruit and vegetables, add sugar and salt to food, is located at $30 \%$ (Table 2).

The frequency higher tobacco and alcohol addiction correspond to the male staff, with increased consumption of tobacco and alcohol of quartermaster personnel risk: $36.5 \%$ and $45.8 \%$ in men, $25.8 \%$ and

\begin{tabular}{|c|c|c|c|c|c|c|}
\hline \multirow{2}{*}{ Demographic characteristics } & \multicolumn{2}{|c|}{ Total } & \multicolumn{3}{c|}{ Age (years) } \\
\cline { 3 - 7 } & Number & $\%$ & $\begin{array}{c}\text { Minimum } \\
\text { value }\end{array}$ & $\begin{array}{c}\text { Maximum } \\
\text { value }\end{array}$ & Media \\
\hline \multirow{3}{*}{ Sex } & Man & 7,347 & 37.6 & 18 & 79 & 40.7 \\
\cline { 2 - 7 } & Woman & 12,185 & 62.3 & 18 & 77 & 40.4 \\
\hline \multirow{4}{*}{ Labor category } & Medical & 3,603 & 18.4 & 22 & 75 & 44.1 \\
\cline { 2 - 7 } & Administrative & 4,264 & 21.8 & 18 & 74 & 41.2 \\
\cline { 2 - 7 } & Quartermaster & 2,581 & 13.2 & 18 & 68 & 33.6 \\
\cline { 2 - 7 } & Other & 9,084 & 46.5 & 18 & 73 & 41.6 \\
\hline
\end{tabular}

Table 1: Demographic characteristics and categories of the IMSS workers.
$21.0 \%$ in women respectively. The consumption of more than five cigarettes a day, affecting a quarter of smokers, staff is the most affected with $9.2 \%$. With respect to behaviors that indicate alcohol addiction, as often corresponds to the unit 1 which applies to drink more alcohol than was initially planned. Quartermaster staff does in $26.5 \%$ men and $17.4 \%$ women. Highlights the increased frequency of this same 1 dependence among medical $12.9 \%$ compared to doctors $9.0 \%$, likewise was also higher frequencies compared between physicians and medical in addiction to alcohol with unit 3, 4 and alcoholic withdrawal syndrome. The Nuevo Leon delegation resulted in 3 occasions, higher for smoking and southern Veracruz for alcoholism on 4 occasions (Table 3).

The highest frequencies of chronic diseases correspond to the male staff, except for obesity, depression, and neoplasm's. It is doubled in men in Dyslipidemia, cardiac infarction and overweight have metabolic syndrome and is doubled in women in depression and neoplasm's. It is similar in both men and women for cerebral vascular complications. The doctors the frequency of dislipidemia is doubled when compared with the medical and in these double when compared with other job categories. The southern Veracruz delegation resulted in 4 times higher for overweight, obesity, hypertension, and Hidalgo in cirrhosis and metabolic syndrome (Table 4).

The likelihood of obesity was statistically significant in both men and women affected by habits of consumption of unhealthy foods, lack of consumption of healthy foods (fruits and vegetables), and in women with the bad habit of fasting. The highest Association occurred in the sedentary life in both sexes.

There was no statistical association with the habit of adding salt to

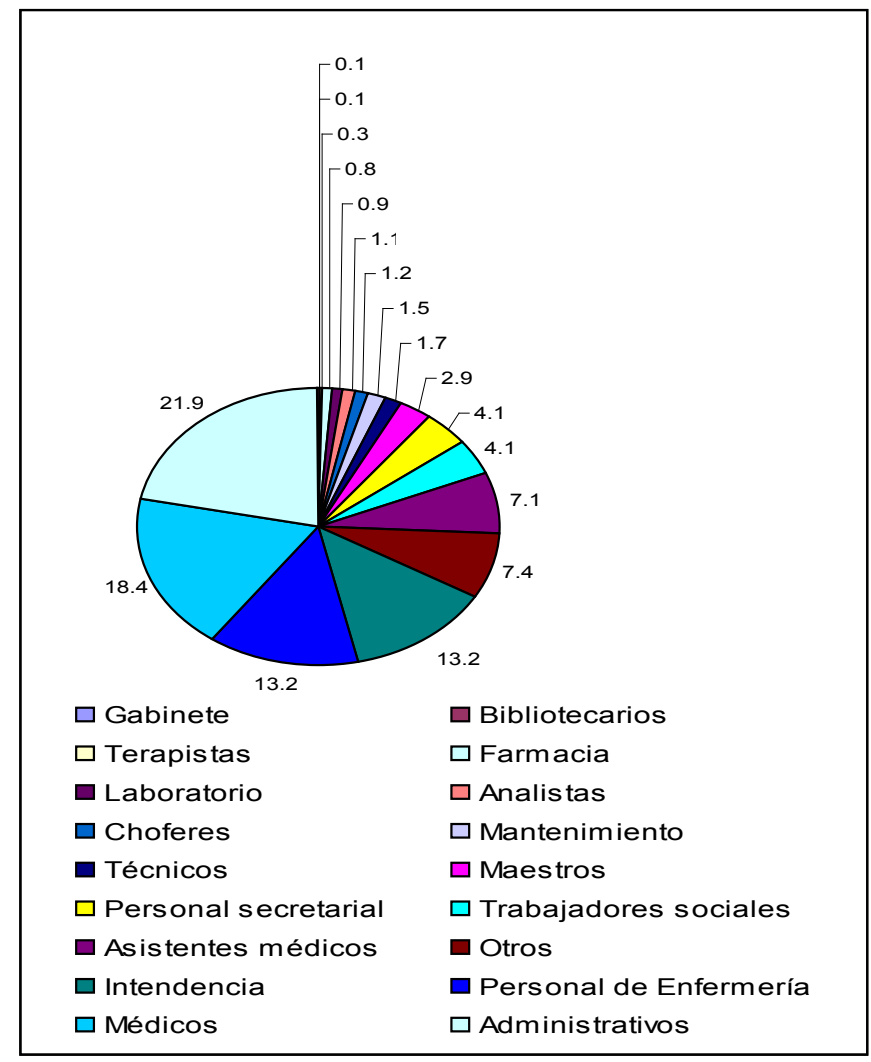

\begin{tabular}{|c|c|c|c|}
\hline \multirow{2}{*}{ DELEGACION } & \multirow{2}{*}{ TOTAL } & \multicolumn{2}{|c|}{ Hombres } \\
\cline { 2 - 4 } & $\begin{array}{c}\text { Edad } \\
\text { promedio }\end{array}$ & $\begin{array}{c}\text { Edad } \\
\text { promedio }\end{array}$ \\
\hline Aguascaliente & 43 & 39 & 44 \\
\hline Baja Californi: & 40 & 40 & 40 \\
\hline $\begin{array}{c}\text { Baja Californi: } \\
\text { Sur }\end{array}$ & 39 & 35 & 42 \\
\hline Campeche & 40 & 41 & 38 \\
\hline Coahuila & 40 & 44 & 43 \\
\hline Colima & 44 & 43 & 40 \\
\hline Chiapas & 39 & 39 & 40 \\
\hline Chihuahua & 41 & 41 & 41 \\
\hline Durango & 40 & 39 & 41 \\
\hline Guanajuato & 38 & 37 & 38 \\
\hline Guerrero & 42 & 43 & 41 \\
\hline Hidalgo & 39 & 39 & 40 \\
\hline Jajisco & 38 & 39 & 37 \\
\hline Mexico Orient & 38 & 37 & 39 \\
\hline Mexico Ponien & 40 & 38 & 40 \\
\hline Michoacan & 42 & 43 & 41 \\
\hline Morelos & 37 & 40 & 37 \\
\hline Nayarit & 40 & 40 & 41 \\
\hline Nuevo Leon & 40 & 40 & 40 \\
\hline Oaxaca & 42 & 42 & 42 \\
\hline Puebia & 41 & 41 & 41 \\
\hline Queretaro & 39 & 40 & 39 \\
\hline Quintana Roc & 38 & 39 & 37 \\
\hline San Luis Poto & 40 & 39 & 40 \\
\hline Sinaloa & 40 & 39 & 40 \\
\hline Sonara & 39 & 40 & 39 \\
\hline Tabasco & 41 & 41 & 41 \\
\hline Tamaulipas & 40 & 40 & 40 \\
\hline Tlaxcala & 41 & 43 & 40 \\
\hline Veracruz Nort & 42 & 43 & 41 \\
\hline Veracruz Sur & 41 & 41 & 40 \\
\hline Yucatan & 41 & 42 & 41 \\
\hline Zacatecas & 42 & 41 & 42 \\
\hline DF Norte & 41 & 40 & 41 \\
\hline DF Sur & 40 & 41 & 40 \\
\hline NACIONAL & 40 & 40 & 40 \\
\hline & & & \\
\hline
\end{tabular}

Figure 1: Proportion by type of all labour categories and age average of men and women workers by delegation. 
Citation: Velasco-Contreras Grado ME (2014) Does Smoking and Alcohol Abuse Precipitate and Aggravate the Risk of Metabolic Syndrome? J Metabolic Synd 3: 141. doi:10.4172/2167-0943.1000141

Page 5 of 12

\begin{tabular}{|c|c|c|c|c|c|c|c|c|c|c|}
\hline \multirow{3}{*}{ Habits of risk } & \multirow{2}{*}{\multicolumn{2}{|c|}{ Overall prevalence }} & \multicolumn{4}{|c|}{ Personal health } & \multicolumn{2}{|c|}{ Other employment category } & \multicolumn{2}{|c|}{ Higher prevalence } \\
\hline & & & \multicolumn{2}{|c|}{ Medical } & \multicolumn{2}{|c|}{ Nurses (I) } & \multirow{2}{*}{$\begin{array}{c}\text { Men } \\
\text { Driver }\end{array}$} & \multirow{2}{*}{$\begin{array}{c}\text { Women } \\
\text { Administrative }\end{array}$} & \multirow{2}{*}{$\begin{array}{l}\text { Men } \\
\text { ZAC }\end{array}$} & \multirow{2}{*}{$\begin{array}{c}\text { Women } \\
\text { NAY }\end{array}$} \\
\hline & Men & Women & Men & Women & Men & Women & & & & \\
\hline + Sedentary lifestyle & 88.9 & 92.8 & 88.7 & 90.5 & 88.3 & 95.0 & 90.4 & 93.6 & 97.4 & 97.2 \\
\hline * Consumes & & & & & & & Quartermaster & Quartermaster & YUC & VERS \\
\hline \multirow[t]{2}{*}{ Excess calories } & 36.4 & 31.9 & 23.3 & 18.8 & 48.8 & 28.3 & 45.4 & 49.1 & 77.3 & 50.8 \\
\hline & & & & & & & Quartermaster & Quartermaster & YUC & YUC \\
\hline \multirow[t]{2}{*}{ Meals Fast } & 30.5 & 22.8 & 18.6 & 13.6 & 40.3 & 15.6 & 41.5 & 44.8 & 50.0 & 47.2 \\
\hline & & & & & & & Quartermaster & Quartermaster & YUC & YUC \\
\hline \multirow[t]{2}{*}{ Scrap } & 42.8 & 40.6 & 29.3 & 25.8 & 48.4 & 31.4 & 56.2 & 55.7 & 70.5 & 66 \\
\hline & & & & & & & Quartermaster & Quartermaster & MEXORO & MEXORO \\
\hline \multirow[t]{2}{*}{ Sweet bread } & 51.4 & 56.5 & 35.4 & 31.9 & 55.8 & 46.3 & 61.1 & 55.7 & 84.1 & 79.1 \\
\hline & & & & & & & Driver & Quartermaster & ZAC & NL \\
\hline \multirow[t]{2}{*}{ More than 5 tortillas per day } & 16.8 & 7.4 & 10.8 & 4.3 & 17.5 & 6.8 & 20.6 & 11.4 & 24.4 & 22.8 \\
\hline & & & & & & & Technical & Quartermaster & AGC & MOR \\
\hline \multirow[t]{2}{*}{$\begin{array}{l}\text { Add } 2 \text { or more } \\
\text { c/sugar/day }\end{array}$} & 28.9 & 26.7 & 20.4 & 17.1 & 28.9 & 26.3 & 34.8 & 36.1 & 45.5 & 36.6 \\
\hline & & & & & & & Quartermaster & Quartermaster & MOR & CAM \\
\hline \multirow[t]{2}{*}{ Add salt } & 52.9 & 53.6 & 42.7 & 41.3 & 50.0 & 50.7 & 63.3 & 65.7 & 66.3 & 62.2 \\
\hline & & & & & & & Quartermaster & Quartermaster & NL & YUC \\
\hline \multirow[t]{2}{*}{ Does not consume daily vegetable } & 39.4 & 34.0 & 26.4 & 21.6 & 35.9 & 28.8 & 46.6 & 47.4 & 48.8 & 49.1 \\
\hline & & & & & & & Driver & Quartermaster & NL & YUC \\
\hline \multirow[t]{2}{*}{ Does not consume fruit daily } & 39.5 & 30.0 & 26.4 & 21.6 & 36.2 & 22.3 & 47.2 & 42.9 & 54.9 & 51.7 \\
\hline & & & & & & & Administrative & Quartermaster & MEXPO & $\mathrm{COAH}$ \\
\hline Does 3 Meals/day & 30.0 & 31.6 & 31.1 & 28.5 & 29.8 & 31.2 & 34.0 & 35.8 & 44.6 & 48.6 \\
\hline
\end{tabular}

Risk habits: behaviors or unhealthy habits that increase the probability of suffering from chronic diseases associated with obesity. + Sedentary lifestyle: Does physical exercise; *Consume for 4 to 7 days a week;

Excess calories: tamales, atoles, capeados, breaded, and fried.

Fast foods: hot dog, pizza, chicken style Kentucky.

Scrap: chips, cakes, biscuits, instant soups, soft drinks. Sweet bread 2 and more servings a day.

Unhealthy eating habits:

- Eating more than 5 tortillas a day.

- Add 2 and more tablespoons of sugar a day.

- Add salt to your food to consume them.

- Does not consume vegetables every day.

- Does not consume fruit every day.

- Does not 3 meals every day (he is fasting, only dinner)

Table 2: Practice of physical exercise and eating habits

consume their food in both sexes and in men although women with the consumption of fast foods, sweet bread and not make 3 meals or have fast men. In general, the Association of these factors with obesity was higher in women (Table 5).

Obesity is associated in men and women with smoking 5 or more cigarettes a day and is statistically significant. Respect to the Association of obesity with the consumption of alcohol risk and their addiction; It arose only in men with alcohol consumption risk, tolerance and dependence to alcohol from 1 to 4 and alcoholic withdrawal syndrome. There was no association with obesity in women who consume alcohol. (Table 6).

The likely to have chronic diseases was statistically significant in both men and women affected by obesity. There was no association with neoplasias. The strength of Association of obesity, with the presence of chronic diseases was higher in women than in men, except in cardiac infarction and cirrhosis of the liver. Chronic diseases in order of magnitude and strength of association with obesity are high blood pressure and diabetes mellitus, Dyslipidemia, and chronic obstructive pulmonary disease in women (Table 7).

Smoking at least one cigarette a day is associated with depression and was statistically significant in both men and women, with greater strength in women in whom also strongly with myocardial infarction and vascular disease (Table 8).
The Association of smoking more 5 cigarettes a day is strongly associated with depression in both sexes, with hypertension, diabetes mellitus, cardiac infarction, vascular disease brain; it was statistically significant, with higher strength of Association in men, except with chronic obstructive pulmonary disease, which was associated with greater strength in women. Dyslipidemia and neoplasms were only associated with intense smoking in women and liver cirrhosis associated with only in men (Table 9).

Alcohol consumption is associated with risk of depression in men and women with 4 times more force in them, as well as cerebral vascular disease only in them. Dyslipidemia is associated only in men (Table 10).

There is association with chronic disease and the consumption of alcohol with unit 4 . They include hypertension, diabetes mellitus, and myocardial infarction with strong association in women and cirrhosis in both sexes. Depression is more strongly associated in men. There were only Association in men with neoplasms, lung disease and cerebral vascular disease. There were no cases of lung disease, or cerebral vascular disease in women.

Association of hypertension and diabetes mellitus risk factors with other chronic diseases addiction to tobacco, alcohol causes irreversible consequences (Table 11 and 12). 
Citation: Velasco-Contreras Grado ME (2014) Does Smoking and Alcohol Abuse Precipitate and Aggravate the Risk of Metabolic Syndrome? J Metabolic Synd 3: 141. doi:10.4172/2167-0943.1000141

Page 6 of 12

\begin{tabular}{|c|c|c|c|c|c|c|c|c|c|c|}
\hline \multirow{3}{*}{ *Addiction } & \multirow{2}{*}{\multicolumn{2}{|c|}{ Overall prevalence }} & \multicolumn{4}{|c|}{ Personal health } & \multicolumn{2}{|c|}{ Other employment category } & \multicolumn{2}{|c|}{ Higher prevalence } \\
\hline & & & \multicolumn{2}{|c|}{ Medical } & \multicolumn{2}{|c|}{ Nurses (I) } & \multirow{2}{*}{$\begin{array}{c}\text { Men } \\
\text { Quartermaster }\end{array}$} & \multirow{2}{*}{$\begin{array}{c}\text { Women } \\
\text { Quartermaster }\end{array}$} & \multirow{2}{*}{$\begin{array}{c}\text { Men } \\
\mathrm{NL}\end{array}$} & \multirow{2}{*}{$\begin{array}{c}\text { Women } \\
\text { JAL }\end{array}$} \\
\hline & Men & Women & Men & Women & Men & Women & & & & \\
\hline \multirow[t]{2}{*}{ Smoking } & 26.1 & 13.1 & 14.9 & 8.4 & 29.9 & 8.8 & 36.5 & 25.8 & 37.7 & 18.3 \\
\hline & & & & & & & Technical & Quartermaster & NL & NL \\
\hline \multirow[t]{2}{*}{ Smoking + 5 cigars Per day } & 6.5 & 2.2 & 4.0 & 2.0 & 5.2 & 0.9 & 9.2 & 4.8 & 9.2 & 4.8 \\
\hline & & & & & & & Quartermaster & Quartermaster & $\mathrm{CHIH}$ & $\mathrm{COL}$ \\
\hline \multirow[t]{2}{*}{ Alcohol consumption Risk } & 40.3 & 12.7 & 34.4 & 9.9 & 39.6 & 9.0 & 45.8 & 21.0 & 51.7 & 24.5 \\
\hline & & & & & & & Quartermaster & Quartermaster & VERS & VERS \\
\hline \multirow[t]{2}{*}{ Unit 1} & 18.6 & 10.1 & 9.0 & 12.9 & 20.0 & 8.4 & 26.5 & 17.4 & 43.1 & 33.3 \\
\hline & & & & & & & Quartermaster & Quartermaster & TLAX & VERS \\
\hline \multirow[t]{2}{*}{ Unit 2} & 16.7 & 8.2 & 7.1 & 4.9 & 19.8 & 5.3 & 26.8 & 12.7 & 44.8 & 29.0 \\
\hline & & & & & & & Quartermaster & Quartermaster & MEXPO & OAX \\
\hline \multirow[t]{2}{*}{ Tolerance } & 12.3 & 4.5 & 5.8 & 3.4 & 14.2 & 3.0 & 16.9 & 8.1 & 24.4 & 16.7 \\
\hline & & & & & & & Quartermaster & Quartermaster & VERN & VERS \\
\hline \multirow[t]{2}{*}{ Unit 3} & 10.4 & 4.6 & 4.0 & 4.3 & 11.3 & 2.0 & 17.0 & 9.2 & 29.6 & 33.3 \\
\hline & & & & & & & Quartermaster & Quartermaster & TLAX & TAB \\
\hline \multirow[t]{2}{*}{ Unit 4} & 3.4 & 1.2 & 0.8 & 1.6 & 4.7 & 0.4 & 5.2 & 1.7 & 10.3 & 6.6 \\
\hline & & & & & & & Quartermaster & Quartermaster & $\mathrm{COAH}$ & OAX \\
\hline Alcohol withdrawal syndrome & 4.0 & 2.0 & 1.2 & 2.5 & 6.3 & 1.2 & 5.5 & 4.1 & 9.6 & 11.1 \\
\hline
\end{tabular}

*Addictions: Chronic diseases by periodic consumption of legal drugs: nicotine or alcohol. Risk alcohol consumption. In the past 12 months has drunk 3 or more alcoholic drinks in one period of less than 3 hours or more than 3 times.

Tolerance: You had the need to drink more to achieve the same effect.

Unit 1: when you drink alcohol, ends up drinking more than what was initially planned.

Unit 2: has tried to reduce the drinking quantity or stop drinking, but failed.

Unit 3: in the days of baby, spends a number of considerable times to obtain alcohol or drink to recover from its effects.

Unit 4: invest less time in work, enjoy a hobby, or be with others because of his fondness for drink.

Alcohol withdrawal syndrome: when you stop drinking their hands tremble, sweat or feel restless and also drink to avoid these symptoms.

Table 3: Addictions: Smoking and alcoholism.

\begin{tabular}{|c|c|c|c|c|c|c|c|c|c|c|}
\hline \multirow{3}{*}{ * Disease } & \multirow{2}{*}{\multicolumn{2}{|c|}{ Overall prevalence }} & \multicolumn{4}{|c|}{ Personal health } & \multicolumn{2}{|c|}{ Other employment category } & \multicolumn{2}{|c|}{ Higher prevalence } \\
\hline & & & \multicolumn{2}{|c|}{ Medical } & \multicolumn{2}{|c|}{ Nurses (I) } & \multirow{2}{*}{$\begin{array}{c}\text { Men } \\
\text { Master }\end{array}$} & \multirow{2}{*}{$\begin{array}{c}\text { Women } \\
\text { Social work }\end{array}$} & \multirow{2}{*}{$\begin{array}{c}\text { Men } \\
\text { VERS }\end{array}$} & \multirow{2}{*}{$\begin{array}{c}\text { Women } \\
\text { COL }\end{array}$} \\
\hline & Men & Women & Men & Women & Men & Women & & & & \\
\hline \multirow[t]{2}{*}{ Overweight } & 36.5 & 36.4 & 37.7 & 38.5 & 29.9 & 42.8 & 40.5 & 40.8 & 49.5 & 51.9 \\
\hline & & & & & & & Technical & Social work & VERS & VERS \\
\hline \multirow[t]{2}{*}{ Obesity } & 11.4 & 12.9 & 12.1 & 11.9 & 13.4 & 14.7 & 13.9 & 15.7 & 18.4 & 19.1 \\
\hline & & & & & & & Master & Master & VERS & $\mathrm{COL}$ \\
\hline \multirow[t]{2}{*}{ Hypertension } & 12.2 & 11.2 & 16.9 & 12.3 & 12.3 & 10.7 & 12.4 & 13.2 & 20.5 & 16.3 \\
\hline & & & & & & & Technical & Social work & TAB & MEXPO \\
\hline \multirow[t]{2}{*}{ Dyslipidemia } & 8.5 & 5.1 & 19.2 & 10.0 & 6.2 & 6.3 & 5.0 & 6.5 & 14.9 & 15.0 \\
\hline & & & & & & & Master & Master & OAX & SLP \\
\hline \multirow[t]{2}{*}{ Diabetes } & 7.5 & 6.3 & 7.9 & 4.2 & 8.0 & 6.0 & 9.2 & 9.0 & 13.3 & 8.9 \\
\hline & & & & & & & Driver & Master & NAY & $\mathrm{COL}$ \\
\hline \multirow[t]{2}{*}{ Depression } & 2.6 & 4.6 & 2.5 & 4.0 & 2.2 & 3.7 & 5.0 & 6.6 & 5.6 & 5.4 \\
\hline & & & & & & & Therapists & Master & ARE & $\mathrm{COL}$ \\
\hline \multirow[t]{2}{*}{ Cardiac infarct } & 1.3 & 0.7 & 2.0 & 0.7 & 1.1 & 0.4 & 1.5 & 2.1 & 4.1 & 1.9 \\
\hline & & & & & & & Master & Medical Assistant. & SLP & $\mathrm{MICH}$ \\
\hline \multirow[t]{2}{*}{$\begin{array}{l}\text { Chronic obstructive } \\
\text { pulmonary disease }\end{array}$} & 1.0 & 0.8 & 0.8 & 0.6 & 1.1 & 0.5 & 2.0 & 1.0 & 2.3 & 1.9 \\
\hline & & & & & & & Administrative & Master & WITHOUT & MOR \\
\hline \multirow[t]{2}{*}{ Neoplasm's } & 0.5 & 1.2 & 0.7 & 1.5 & 0.4 & 1.4 & 0.5 & 2.1 & 1.8 & 2.8 \\
\hline & & & & & & & Master & Master & PUE & MEXPO \\
\hline \multirow[t]{2}{*}{$\begin{array}{l}\text { Cerebral vascular } \\
\text { disease }\end{array}$} & 0.4 & 0.4 & 0.4 & 0.3 & 0.4 & 0.6 & 0.7 & 1.4 & 1.3 & 1.0 \\
\hline & & & & & & & Quartermaster & Medical Assistant. & HGO & VERN \\
\hline $\begin{array}{l}\text { Cirrhosis of the } \\
\text { liver }\end{array}$ & 0.3 & 0.2 & 0.4 & 0.3 & 0.7 & 0.1 & 0.2 & 0.7 & 2.7 & 1.0 \\
\hline
\end{tabular}


Citation: Velasco-Contreras Grado ME (2014) Does Smoking and Alcohol Abuse Precipitate and Aggravate the Risk of Metabolic Syndrome? J Metabolic Synd 3: 141. doi:10.4172/2167-0943.1000141

Page 7 of 12

\begin{tabular}{|c|c|c|c|c|c|c|c|c|c|c|}
\hline & & & & & & & Driver & Medical Assistant. & HGO & BCS \\
\hline \multirow{2}{*}{$\begin{array}{l}\text { Overweight } \\
\text { and metabolic } \\
\text { syndrome }\end{array}$} & 0.5 & 0.2 & 1.2 & 0.6 & 0.0 & 0.2 & 1.4 & 0.5 & 1.8 & 1.3 \\
\hline & & & & & & & Quartermaster & Social work & HGO & AGC \\
\hline $\begin{array}{l}\text { Metabolic } \\
\text { syndrome and } \\
\text { obesity }\end{array}$ & 0.3 & 0.2 & 0.9 & 0.6 & 0.0 & 0.2 & 0.2 & 0.3 & 2.7 & 1.22 \\
\hline
\end{tabular}

*Diagnostic acquainted with registration: evolution time, number of consultations per year, hospitalizations and disability days in the past year. SM=metabolic syndrome: Overweight/obesity, hypertension, diabetes and Dyslipidemia

Table 4: Frequency of chronic diseases.

\begin{tabular}{|c|c|c|c|c|c|c|c|c|c|c|c|c|}
\hline \multirow{3}{*}{\begin{tabular}{|l} 
Risk factor \\
Sedentary lifestyle
\end{tabular}} & \multicolumn{6}{|c|}{ Obesity in men $11.4 \%$} & \multicolumn{6}{|c|}{ Obesity in women $12.9 \%$} \\
\hline & \multirow{2}{*}{$\begin{array}{c}\text { Prevalence } \\
\text { in exposed } \\
14.3\end{array}$} & \multirow{2}{*}{$\begin{array}{l}\text { RMP } \\
1.83\end{array}$} & \multicolumn{2}{|c|}{ IC } & \multirow{2}{*}{$\begin{array}{l}\text { Xmh } \\
8.05\end{array}$} & \multirow{2}{*}{$\begin{array}{c}+\mathrm{P}<.05 \\
+\end{array}$} & \multirow{2}{*}{$\begin{array}{c}\text { Prevalence } \\
\text { in exposed } \\
15.9\end{array}$} & \multirow{2}{*}{$\begin{array}{l}\text { RMP } \\
2.17\end{array}$} & \multicolumn{2}{|c|}{ IC } & \multirow{2}{*}{$\begin{array}{l}\mathrm{Xmh} \\
12.58\end{array}$} & \multirow{2}{*}{$\begin{array}{c}+\mathrm{P}<.05 \\
+\end{array}$} \\
\hline & & & 1.58 & 2.13 & & & & & 1.92 & 2.45 & & \\
\hline $\begin{array}{l}\text { Eat: } \\
\text { Excess calories }\end{array}$ & 12.1 & 1.68 & 1.33 & 2.11 & 4.47 & + & 13.5 & 1.55 & 1.31 & 1.84 & 5.09 & + \\
\hline Fast foods & 11.7 & 1.15 & 0.97 & 1.38 & 1.60 & & 13.3 & 1.15 & 1.02 & 1.3 & 2.22 & + \\
\hline Scrap & 11.8 & 1.27 & 1.04 & 1.55 & 2.39 & + & 13.7 & 1.61 & 1.37 & 1.88 & 5.91 & + \\
\hline Sweet bread & 11.4 & 1.05 & 0.86 & 1.29 & 0.45 & & 13.2 & 1.23 & 1.06 & 1.44 & 2.67 & + \\
\hline $\begin{array}{l}\text { More than 5tortillas per } \\
\text { day }\end{array}$ & 11.4 & 1.21 & 0.61 & 2.42 & 0.54 & & 13.1 & 1.43 & 1.44 & 4.11 & 3.43 & + \\
\hline More than $2 \mathrm{c} / \mathrm{sugar}$ day & 13.3 & 1.3 & 1.12 & 1.52 & 3.35 & + & 16.3 & 1.48 & 1.32 & 1.65 & 6.72 & + \\
\hline Add salt & 11.8 & 1.1 & 0.96 & 1.28 & 1.34 & & 12.6 & 0.95 & 0.85 & 1.05 & -1.03 & \\
\hline $\begin{array}{l}\text { Does not consume } \\
\text { vegetables }\end{array}$ & 13.4 & 1.38 & 1.19 & 1.6 & 4.36 & + & 15.2 & 1.34 & 1.2 & 1.49 & 5.19 & + \\
\hline Does not consume fruit & 13.8 & 1.43 & 1.23 & 1.66 & 4.74 & + & 15.8 & 1.39 & 1.24 & 1.56 & 5.69 & + \\
\hline Do 3 meals & 12.5 & 1.16 & 0.99 & 1.37 & 1.81 & & 14.5 & 2.08 & 1.36 & 3.29 & 6.72 & + \\
\hline
\end{tabular}

*Global prevalence of obesity in men and women. $\mathrm{PE}=$ prevalence in exposed (with the risk factor) RMP=reason for the prevalence odds, $\mathrm{Cl}=$ confidence interval; $\mathrm{Xmh}=$ Chi-square of Mantel-Haenszel.

Table 5: Association of obesity with poor diet and sedentary lifestyle habits.

\begin{tabular}{|c|c|c|c|c|c|c|c|c|c|c|c|c|}
\hline \multirow{4}{*}{$\begin{array}{l}\text { Risk factors } \\
\text { Smoking }\end{array}$} & \multicolumn{12}{|c|}{ Table of contingency, degree of Association and statistical significance } \\
\hline & \multicolumn{6}{|c|}{ Obesity in men $11.4 \%$} & \multicolumn{6}{|c|}{ Obesity in women $12.9 \%$} \\
\hline & \multirow{2}{*}{$\begin{array}{c}\text { Prevalence } \\
\text { in exposed } \\
11.9\end{array}$} & \multirow{2}{*}{$\begin{array}{l}\text { RMP } \\
1.08\end{array}$} & \multicolumn{2}{|c|}{ IC } & \multirow{2}{*}{$\begin{array}{l}\mathrm{Xmh} \\
0.81\end{array}$} & \multirow[t]{2}{*}{$\begin{array}{l}+\mathrm{P} \\
<.05\end{array}$} & \multirow{2}{*}{$\begin{array}{c}\text { Prevalence } \\
\text { in exposed } \\
13.9\end{array}$} & \multirow{2}{*}{$\begin{array}{l}\text { RMP } \\
1.10\end{array}$} & \multicolumn{2}{|c|}{ IC } & \multirow{2}{*}{$\begin{array}{l}\mathrm{Xmh} \\
1.20\end{array}$} & \multirow[t]{2}{*}{$\begin{array}{l}+\mathrm{P} \\
<.05\end{array}$} \\
\hline & & & 0.91 & 1.29 & & & & & 0.95 & 1.29 & & \\
\hline $\begin{array}{l}\text { You smoke more than five cigarettes } \\
\text { a day }\end{array}$ & 15.3 & 1.44 & 1.11 & 1.88 & 2.71 & + & 17.4 & 1.43 & 1.03 & 1.98 & 2.17 & + \\
\hline $\begin{array}{l}\text { Consumption of Alcohol in } \\
\text { Risk }\end{array}$ & 15.8 & 1.81 & 1.57 & 2.10 & 8.00 & + & 13.3 & 1.04 & 0.89 & 1.23 & 0.52 & \\
\hline Tolerance & 20.2 & 2.08 & 1.61 & 2.69 & 5.67 & + & 15.6 & 1.25 & 0.70 & 2.21 & 0.75 & \\
\hline $\begin{array}{l}\text { Deprivation syndrome } \\
\text { Alcoholic }\end{array}$ & 23.6 & 2.46 & 1.61 & 3.75 & 4.31 & + & 10.8 & 0.82 & 0.29 & 2.31 & -0.38 & \\
\hline Unit 1 & 15.1 & 1.43 & 1.12 & 1.82 & 2.91 & + & 12.0 & 0.92 & 0.59 & 1.44 & -0.35 & \\
\hline Unit 2 & 15.4 & 1.46 & 1.13 & 1.88 & 2.93 & + & 10.7 & 0.81 & 0.47 & 1.38 & -0.77 & \\
\hline Unit 3 & 14.6 & 1.36 & 0.98 & 1.87 & 1.85 & & 8.9 & 0.65 & 0.30 & 1.43 & -1.075 & \\
\hline Unit 4 & 20.4 & 2.03 & 1.25 & 3.29 & 2.91 & + & 9.5 & 0.71 & 0.17 & 3.05 & -0.46 & \\
\hline
\end{tabular}

Smoking: Chronic disease by the consumption of nicotine in cigarettes. Risk alcohol consumption. In the past 12 months has drunk 3 or more alcoholic drinks in one period of less than 3 hours or more than 3 times.

Tolerance: You had the need to drink more to achieve the same effect.

Unit 1: when you drink alcohol, ends up drinking more than what was initially planned.

Unit 2: has tried to reduce the drinking quantity or stop drinking, but failed.

Unit 3: in the days of baby, spends a number of considerable time to obtain alcohol or drink to recover from its effects.

Unit 4: invest less time in work, enjoy a hobby, or be with others because of his fondness for drink.

Alcohol withdrawal syndrome: when you stop drinking their hands tremble, sweat or feel restless and also drink to avoid these symptoms.

$\mathrm{RMP}=$ reason for the prevalence odds, $\mathrm{Cl}=\mathrm{RMP}$ confidence interval, $\mathrm{Xmh}=$ Chi-square ofMantel-Haenszel

Table 6: Association of obesity with smoking and alcoholism 
Citation: Velasco-Contreras Grado ME (2014) Does Smoking and Alcohol Abuse Precipitate and Aggravate the Risk of Metabolic Syndrome? J Metabolic Synd 3: 141. doi:10.4172/2167-0943.1000141

Page 8 of 12

\begin{tabular}{|c|c|c|c|c|c|c|c|c|c|c|c|c|}
\hline \multirow{4}{*}{\begin{tabular}{|l} 
Disease \\
High blood pressure \\
\end{tabular}} & \multicolumn{12}{|c|}{ Table of contingency, degree of Association and statistical significance } \\
\hline & \multicolumn{6}{|c|}{ Obesity in men $11.4 \%$} & \multicolumn{6}{|c|}{ Obesity in women $12.9 \%$} \\
\hline & \multirow{2}{*}{$\begin{array}{c}\begin{array}{c}\text { Prevalence } \\
\text { in exposed }\end{array} \\
23.0\end{array}$} & \multirow{2}{*}{$\begin{array}{l}\text { RMP } \\
2.77\end{array}$} & \multicolumn{2}{|c|}{ IC } & \multirow{2}{*}{$\begin{array}{l}\text { Xmh } \\
11.70\end{array}$} & \multirow{2}{*}{$\begin{array}{c}+P<.05 \\
+\end{array}$} & \multirow{2}{*}{$\begin{array}{c}\text { Prevalence } \\
\text { in exposed } \\
23.8\end{array}$} & \multirow{2}{*}{$\begin{array}{l}\text { RMP } \\
2.40\end{array}$} & \multicolumn{2}{|c|}{ IC } & \multirow{2}{*}{$\begin{array}{l}\text { Xmh } \\
12.70\end{array}$} & \multirow{2}{*}{$\begin{array}{c}+P<.05 \\
+\end{array}$} \\
\hline & & & 2.33 & 3.31 & & & & & 2.09 & 2.75 & & \\
\hline Diabetes mellitus & 21.7 & 2.36 & 1.90 & 2.93 & 7.97 & + & 27.2 & 2.75 & 2.32 & 3.26 & 12.17 & + \\
\hline Dyslipidemia & 22.5 & 2.52 & 2.06 & 3.10 & 9.16 & + & 25.0 & 2.39 & 1.98 & 2.89 & 9.31 & + \\
\hline Depression & 19.5 & 1.93 & 1.34 & 2.78 & 3.57 & + & 18.6 & 1.58 & 1.27 & 1.97 & 4.11 & + \\
\hline Neoplasm's & 16.2 & 1.52 & 0.63 & 3.64 & 0.93 & & 15.2 & 1.22 & 0.78 & 1.90 & 0.86 & \\
\hline $\begin{array}{l}\text { Disease } \\
\text { Pulmonary } \\
\text { OBS. Chronic }\end{array}$ & 22.5 & 2.30 & 1.31 & 4.03 & 2.98 & + & 36.9 & 4.00 & 2.41 & 6.63 & 5.79 & + \\
\hline Cardiac infarct & 33.0 & 3.95 & 2.56 & 6.11 & 6.65 & + & 22.2 & 1.94 & 1.15 & 3.28 & 2.51 & + \\
\hline $\begin{array}{l}\text { Cerebral Vascular } \\
\text { disease }\end{array}$ & 31.8 & 3.67 & 1.49 & 9.02 & 3.03 & + & 32.4 & 3.24 & 1.58 & 6.67 & 3.38 & + \\
\hline Cirrhosis of the liver & 47.8 & 7.24 & 3.18 & 16.46 & 5.52 & + & 37.9 & 4.15 & 1.96 & 8.80 & 4.02 & + \\
\hline
\end{tabular}

$\mathrm{RMP}=$ reason for the prevalence odds, $\mathrm{Cl}=\mathrm{RMP}$ confidence interval, $\mathrm{Xmh}=$ Chi-square ofMantel-Haenszel

Table 7: Association of obesity with chronic diseases of the metabolic syndrome.

Table of contingency, degree of Association and statistical significance

\begin{tabular}{|c|c|c|c|c|c|c|c|c|c|c|c|c|}
\hline \multirow{3}{*}{\begin{tabular}{|l} 
Disease \\
High blood pressure
\end{tabular}} & \multicolumn{6}{|c|}{${ }^{*}$ Men $24.1 \%$} & \multicolumn{6}{|c|}{ * $12.9 \%$ women } \\
\hline & \multirow{2}{*}{$\begin{array}{c}\text { Prevalence } \\
\text { in exposed } \\
19.1\end{array}$} & \multirow{2}{*}{$\begin{array}{c}\text { RMP } \\
0.72\end{array}$} & \multicolumn{2}{|c|}{ IC } & \multirow{2}{*}{$\begin{array}{l}\text { Xmh } \\
-3.70\end{array}$} & \multirow[t]{2}{*}{$+P<.05$} & \multirow{2}{*}{$\begin{array}{c}\text { Prevalence } \\
\text { in exposed } \\
11.5\end{array}$} & \multirow{2}{*}{$\begin{array}{c}\text { RMP } \\
0.86\end{array}$} & \multicolumn{2}{|c|}{ IC } & \multirow{2}{*}{$\begin{array}{c}\text { Xmh } \\
-1.99\end{array}$} & \multirow[t]{2}{*}{$+P<.05$} \\
\hline & & & 0.60 & 0.86 & & & & & 0.73 & 1.03 & & \\
\hline Diabetes mellitus & 24.2 & 1.01 & 0.82 & 1.24 & 0.09 & & 15.0 & 1.21 & 0.98 & 1.48 & 1.78 & \\
\hline Dyslipidemia & 22.0 & 0.88 & 0.72 & 1.08 & -1.24 & & 11.0 & 0.82 & 0.64 & 1.07 & -1.47 & \\
\hline Depression & 34.2 & 1.67 & 1.23 & 2.26 & 3.31 & + & 18.8 & 1.60 & 1.28 & 1.99 & 4.21 & + \\
\hline Neoplasms & 24.3 & 1.01 & 0.48 & 2.15 & 0.04 & & 17.2 & 1.41 & 0.92 & 2.15 & 1.57 & \\
\hline $\begin{array}{l}\text { Disease } \\
\text { Pulmonary } \\
\text { Chronic obstructive }\end{array}$ & 33.8 & 1.62 & 0.99 & 2.66 & 1.92 & & 16.9 & 1.37 & 0.72 & 2.63 & 0.96 & \\
\hline Cardiac infarct & 22.3 & 0.91 & 0.56 & 1.48 & -0.39 & & 28.4 & 2.69 & 1.66 & 4.38 & 4.16 & + \\
\hline $\begin{array}{l}\text { Disease } \\
\text { Vascular brain }\end{array}$ & 31.8 & 1.47 & 0.60 & 3.62 & 0.85 & & 32.4 & 3.24 & 1.58 & 6.66 & 3.38 & + \\
\hline Cirrhosis of the liver & 30.4 & 1.38 & 0.57 & 3.36 & 0.71 & & 10.3 & 0.78 & 0.24 & 2.57 & -0.41 & \\
\hline
\end{tabular}

* Prevalence of smoking in men and women. + currently smoke at least one cigarette every day.

$\mathrm{RMP}=$ reason for the prevalence odds, $\mathrm{Cl}=\mathrm{RMP}$ confidence interval, $\mathrm{Xmh}=\mathrm{Chi}$-square ofMantel-Haenszel

Table 8: Association of chronic diseases with smoking.

Table of contingency, degree of Association and statistical significance

\begin{tabular}{|c|c|c|c|c|c|c|c|c|c|c|c|c|}
\hline \multirow{3}{*}{$\begin{array}{l}\text { Disease } \\
\text { High blood } \\
\text { pressure }\end{array}$} & \multicolumn{6}{|c|}{ Men * $6.2 \%$} & \multicolumn{6}{|c|}{ Women * $2.1 \%$} \\
\hline & \multirow{2}{*}{$\begin{array}{c}\begin{array}{c}\text { Prevalence } \\
\text { in exposed }\end{array} \\
7.7\end{array}$} & \multirow{2}{*}{$\begin{array}{l}\text { RMP } \\
1.30\end{array}$} & \multicolumn{2}{|c|}{ IC } & \multirow{2}{*}{$\begin{array}{l}\mathrm{Xmh} \\
4.31\end{array}$} & \multirow{2}{*}{$\begin{array}{c}+\mathrm{P}<.05 \\
+\end{array}$} & \multirow{2}{*}{$\begin{array}{c}\text { Prevalence } \\
\text { in exposed } \\
2.5\end{array}$} & \multirow{2}{*}{$\begin{array}{l}\text { RMP } \\
1.21\end{array}$} & \multicolumn{2}{|c|}{ IC } & \multirow{2}{*}{$\begin{array}{l}X \mathrm{mh} \\
3.05\end{array}$} & \multirow{2}{*}{$\begin{array}{c}+\mathrm{P}<.05 \\
+\end{array}$} \\
\hline & & & 1.00 & 1.69 & & & & & 0.84 & 1.74 & & \\
\hline Diabetes mellitus & 9.4 & 1.63 & 1.20 & 2.20 & 7.13 & + & 3.3 & 1.61 & 1.06 & 2.46 & 6.82 & + \\
\hline Dyslipidemia & 6.1 & 0.97 & 0.69 & 1.37 & -0.33 & & 2.6 & 1.22 & 0.73 & 2.04 & 2.29 & + \\
\hline Depression & 14.2 & 2.58 & 1.70 & 3.92 & 10.28 & + & 3.9 & 1.97 & 1.26 & 3.07 & 9.16 & + \\
\hline Neoplasms & 10.8 & 1.83 & 0.64 & 5.18 & 1.15 & & 4.6 & 2.27 & 1.05 & 4.90 & 2.15 & + \\
\hline $\begin{array}{l}\text { Disease } \\
\text { Pulmonary } \\
\text { Chronic } \\
\text { obstructive }\end{array}$ & 16.9 & 3.11 & 1.66 & 5.82 & 3.72 & + & 9.2 & 4.77 & 2.04 & 11.15 & 3.98 & + \\
\hline Cardiac infarct & 14.9 & 2.68 & 1.51 & 4.76 & 3.48 & + & 6.2 & 3.07 & 1.23 & 7.65 & 2.53 & + \\
\hline $\begin{array}{l}\text { Cerebral Vascular } \\
\text { disease }\end{array}$ & 27.3 & 5.69 & 2.22 & 14.61 & 4.08 & + & 8.8 & 4.50 & 1.37 & 14.80 & 2.71 & + \\
\hline $\begin{array}{l}\text { Cirrhosis of the } \\
\text { liver }\end{array}$ & 30.4 & 6.65 & 2.72 & 16.25 & 4.80 & + & 6.9 & 3.43 & 0.81 & 14.50 & 1.78 & \\
\hline
\end{tabular}

* Prevalence of smoking in men and women. + Currently smoke 5 cigarettes a day.

$\mathrm{RMP}=$ reason for the prevalence odds, $\mathrm{Cl}=\mathrm{RMP}$ confidence interval, $\mathrm{Xmh}=\mathrm{Chi}$-square ofMantel-Haenszel,

Table 9: Association of chronic diseases with smoking 5 cigarettes a day. 
Citation: Velasco-Contreras Grado ME (2014) Does Smoking and Alcohol Abuse Precipitate and Aggravate the Risk of Metabolic Syndrome? J Metabolic Synd 3: 141. doi:10.4172/2167-0943.1000141

Page 9 of 12

\begin{tabular}{|c|c|c|c|c|c|c|c|c|c|c|c|c|}
\hline \multirow{3}{*}{$\begin{array}{l}\text { Disease } \\
\text { High blood } \\
\text { pressure }\end{array}$} & \multicolumn{6}{|c|}{ Men * $38.4 \%$} & \multicolumn{6}{|c|}{ Women * $11.4 \%$} \\
\hline & \multirow{2}{*}{$\begin{array}{c}\text { Prevalence } \\
\text { in exposed } \\
39.6\end{array}$} & \multirow{2}{*}{$\begin{array}{l}\text { RMP } \\
1.06\end{array}$} & \multicolumn{2}{|c|}{ IC } & \multirow{2}{*}{$\begin{array}{l}\mathrm{Xmh} \\
0.78\end{array}$} & \multirow[t]{2}{*}{$+\mathrm{P}<.05$} & \multirow{2}{*}{$\begin{array}{c}\begin{array}{c}\text { Prevalence } \\
\text { in exposed }\end{array} \\
8.9\end{array}$} & \multirow{2}{*}{$\begin{array}{l}\text { RMP } \\
0.74\end{array}$} & \multicolumn{2}{|c|}{ IC } & \multirow{2}{*}{$\begin{array}{l}\mathrm{Xmh} \\
-3.09\end{array}$} & \multirow[t]{2}{*}{$+P<.05$} \\
\hline & & & 0.92 & 1.22 & & & & & 0.60 & 0.89 & & \\
\hline Diabetes mellitus & 37.4 & 0.96 & 0.80 & 1.15 & -0.46 & & 10.6 & 0.92 & 0.72 & 1.16 & -0.72 & \\
\hline Dyslipidemia & 43.4 & 1.26 & 1.07 & 1.48 & 2.70 & + & 12.8 & 1.15 & 0.90 & 1.46 & 1.10 & \\
\hline Depression & 48.4 & 1.53 & 1.14 & 2.04 & 2.89 & + & 22.2 & 2.33 & 1.90 & 2.87 & 8.21 & + \\
\hline Neoplasms & 35.1 & 0.87 & 0.44 & 1.71 & -0.40 & & 11.9 & 1.05 & 0.64 & 1.73 & 0.20 & \\
\hline $\begin{array}{l}\text { Disease } \\
\text { Pulmonary } \\
\text { Chronic } \\
\text { obstructive }\end{array}$ & 46.5 & 1.40 & 0.88 & 2.24 & 1.41 & & 15.4 & 1.42 & 0.72 & 2.78 & 1.01 & \\
\hline Cardiac infarct & 34.0 & 0.83 & 0.54 & 1.27 & -0.86 & & 14.8 & 1.35 & 0.73 & 2.51 & 0.97 & \\
\hline $\begin{array}{l}\text { Cerebral Vascular } \\
\text { disease }\end{array}$ & 54.5 & 1.93 & 0.83 & 4.48 & 1.56 & & 23.5 & 2.40 & 1.08 & 5.31 & 2.22 & + \\
\hline $\begin{array}{l}\text { Cirrhosis of the } \\
\text { liver }\end{array}$ & 47.8 & 1.48 & 0.65 & 3.35 & 0.94 & & 13.8 & 1.24 & 0.43 & 3.58 & 0.40 & \\
\hline
\end{tabular}

Table 10: Association of chronic diseases with risk alcohol consumption.

Table of contingency, degree of Association and statistical significance

\begin{tabular}{|c|c|c|c|c|c|c|c|c|c|c|c|c|}
\hline \multirow{3}{*}{$\begin{array}{l}\text { Disease } \\
\text { High blood pressure }\end{array}$} & \multicolumn{6}{|c|}{ Men * $1.4 \%$} & \multicolumn{6}{|c|}{ Women * $0.2 \%$} \\
\hline & \multirow{2}{*}{$\begin{array}{c}\text { Prevalence } \\
\text { in exposed } \\
2.2\end{array}$} & \multirow{2}{*}{$\begin{array}{l}\text { RMP } \\
1.75\end{array}$} & \multicolumn{2}{|c|}{ IC } & \multirow{2}{*}{$\begin{array}{l}\mathrm{Xmh} \\
2.26\end{array}$} & \multirow{2}{*}{$\begin{array}{c}+\mathrm{P}<.05 \\
+\end{array}$} & \multirow{2}{*}{$\begin{array}{c}\text { Prevalence } \\
\text { in exposed } \\
0.4\end{array}$} & \multirow{2}{*}{$\begin{array}{l}\text { RMP } \\
2.99\end{array}$} & \multicolumn{2}{|c|}{ IC } & \multirow{2}{*}{$\begin{array}{l}\mathrm{Xmh} \\
2.40\end{array}$} & \multirow{2}{*}{$\begin{array}{c}+\mathrm{P}<.05 \\
+\end{array}$} \\
\hline & & & 1.07 & 2.87 & & & & & 1.17 & 7.66 & & \\
\hline Diabetes mellitus & 2.5 & 1.96 & 1.11 & 3.46 & 2.35 & + & 0.7 & 4.69 & 1.71 & 12.80 & 3.31 & + \\
\hline Dyslipidemia & 1.4 & 1.04 & 0.52 & 2.06 & 0.10 & & 0.2 & 0.92 & 0.12 & 6.88 & -0.80 & \\
\hline Depression & 5.8 & 4.72 & 2.48 & 8.97 & 5.21 & + & 0.7 & 4.92 & 1.65 & 14.68 & 3.17 & + \\
\hline Neoplasms & 8.1 & 6.36 & 1.92 & 21.06 & 3.47 & + & 0.7 & 4.00 & 0.53 & 30.03 & 1.46 & \\
\hline $\begin{array}{l}\text { Disease } \\
\text { Pulmonary } \\
\text { Obstructive. Chronic }\end{array}$ & 4.2 & 3.17 & 0.98 & 10.23 & 2.03 & + & 0.0 & 0.00 & 0.00 & 0.00 & 0.00 & \\
\hline Cardiac infarct & 4.3 & 3.21 & 1.16 & 8.92 & 2.36 & + & 3.7 & 25.82 & 7.46 & 98.40 & 7.68 & + \\
\hline $\begin{array}{l}\text { Disease. Vascular } \\
\text { brain }\end{array}$ & 9.1 & 7.15 & 1.65 & 31.01 & 3.07 & + & 0.0 & 0.00 & 0.00 & 0.00 & 0.00 & \\
\hline Cirrhosis of the liver & 17.4 & 15.36 & 5.13 & 45.99 & 6.53 & + & 3.4 & 21.67 & 2.81 & 167.06 & 4.25 & + \\
\hline
\end{tabular}

* Prevalence of alcohol-dependent 4: invest time to get alcohol and drink or drinks to recover from its effects

$\mathrm{RMP}=$ reason for the prevalence odds, $\mathrm{Cl}=\mathrm{RMP}$ confidence interval, $\mathrm{Xmh}=$ Chi-square ofMantel-Haenszel,

Table 11: Association of chronic diseases with 4 alcohol dependence

\begin{tabular}{|c|c|c|c|c|c|c|c|c|c|c|c|c|}
\hline \multirow{3}{*}{\begin{tabular}{|l|} 
Risk factors \\
Add sugar \\
\end{tabular}} & \multicolumn{6}{|c|}{ Workers with hypertension 2252} & \multicolumn{6}{|c|}{ Workers withDiabetes mellitus 1329} \\
\hline & \multirow{2}{*}{$\begin{array}{c}\text { Prevalence } \\
\text { in exposed } \\
16.1\end{array}$} & \multirow{2}{*}{$\begin{array}{l}\text { RMP } \\
\mathbf{1 . 3 6}\end{array}$} & \multicolumn{2}{|c|}{ IC } & \multirow{2}{*}{$\begin{array}{r}\mathrm{Xmh} \\
2.0\end{array}$} & \multirow{2}{*}{$\begin{array}{c}+\mathrm{P}<.05 \\
+\end{array}$} & \multirow{2}{*}{$\begin{array}{c}\begin{array}{c}\text { Prevalence } \\
\text { in exposed }\end{array} \\
15.8\end{array}$} & \multirow{2}{*}{$\begin{array}{l}\text { RMP } \\
2.63\end{array}$} & \multicolumn{2}{|c|}{ IC } & \multirow{2}{*}{$\begin{array}{r}X \mathrm{mh} \\
3.48\end{array}$} & \multirow{2}{*}{$\begin{array}{c}+\mathrm{P}<.05 \\
+\end{array}$} \\
\hline & & & 1.16 & 1.61 & & & & & 2.01 & 3.44 & & \\
\hline Sedentary lifestyle & 15.0 & 1.34 & 1.13 & 1.59 & 1.7 & & 7.4 & 1.15 & 0.86 & 1.56 & 0.35 & \\
\hline Overweight & 13.2 & 1.14 & 0.96 & 1.36 & 0.7 & & 7.1 & 0.99 & 0.74 & 1.32 & -0.03 & \\
\hline Smoking & 15.4 & 1.31 & 1.11 & 1.55 & 1.7. & & 10.7 & 1.65 & 1.25 & 2.17 & 1.49 & \\
\hline $\begin{array}{l}\text { Consumption of } \\
\text { alcohol of } \\
\text { risk }\end{array}$ & 13.5 & 1.12 & 0.96 & 1.36 & 0.68 & & 7.5 & 104 & 0.78 & 1.39 & 0.10 & \\
\hline DISEASES & \multicolumn{12}{|c|}{ Associated diseases } \\
\hline Obesity & 22.5 & 2.11 & 1.8 & 2.47 & 5.5 & + & 13.5 & 2.16 & 1.65 & 2.83 & 2.5 & + \\
\hline $\begin{array}{l}\text { Diabetes I } \\
\text { Hypertension }\end{array}$ & 37.0 & 3.70 & 3.18 & 4.31 & 12.6 & + & 21.6 & 4.15 & 3.16 & 5.46 & 5.84 & + \\
\hline Dyslipidemia & 25.5 & 2.26 & 1.94 & 2.64 & 6.6 & + & 13.1 & 1.89 & 1.46 & 2.46 & 2.19 & + \\
\hline Depression & 21.0 & 1.74 & 1.49 & 2.04 & 4.1 & + & 11.4 & 1.59 & 1.22 & 2.08 & 1.5 & + \\
\hline Neoplasms (cancer) & 23.4 & 1.9 & 1.63 & 2.21 & 5.16 & + & 28.1 & 4.01 & 3.17 & 5.08 & 7.5 & + \\
\hline COMPLICATIONS & \multicolumn{12}{|c|}{ Associated irreversible sequelae and complications } \\
\hline Cardiac infarct & 56.0 & 5.06 & 4.4 & 5.81 & 20.9 & + & 41.7 & 6.16 & 4.9 & 7.76 & 12.4 & + \\
\hline $\begin{array}{l}\text { Disease } \\
\text { Vascular } \\
\text { Brain }\end{array}$ & 48.2 & 4.19 & 3.64 & 4.82 & 17.1 & + & 24 & 3.36 & 2.65 & 4.26 & 5.9 & + \\
\hline
\end{tabular}




\begin{tabular}{|c|c|c|c|c|c|c|c|c|c|c|c|c|}
\hline \begin{tabular}{|l} 
Disease \\
Pulmonary \\
Obstructive \\
chronic
\end{tabular} & 34.8 & 2.93 & 2.54 & 3.38 & 10.6 & + & 25 & 3.5 & 2.76 & 4.44 & 6.3 & + \\
\hline Liver cirrhosis & 44.2 & 3.7 & 3.28 & 4.34 & 15.1 & + & 46.1 & 6.65 & 5.3 & 8.33 & 13.9 & + \\
\hline SMOKING & \multicolumn{12}{|c|}{ Complications and irreversible consequences associated with smoking more than 5 cigarettes a day } \\
\hline Cardiac infarct & 34.6 & 2.88 & 2.5 & 3.33 & 10.5 & + & 37.5 & 50.8 & 26.5 & 97.2 & 13.1 & + \\
\hline $\begin{array}{l}\text { Disease } \\
\text { Vascular } \\
\text { Brain }\end{array}$ & 26.8 & 85.6 & 40.12 & 182.9 & 12.6 & + & 31.2 & 97.8 & 36.4 & 262.5 & 11.0 & + \\
\hline $\begin{array}{l}\text { Disease } \\
\text { Pulmonary } \\
\text { Obstructive } \\
\text { chronic }\end{array}$ & 34.4 & 55.9 & 32.9 & 95.8 & 16.1 & + & 44.1 & 70.3 & 34.9 & 141.5 & 15.8 & + \\
\hline Neoplasms (cancer) & 25.5 & 27.05 & 17.3 & 42.1 & 11.7 & + & 26.9 & 31.4 & 17.7 & 57.8 & 9.3 & + \\
\hline ALCOHOLISM & \multicolumn{12}{|c|}{ Complications and irreversible consequences associated with alcohol consumption with unit 4} \\
\hline Cardiac infarct & 27.5 & 37.7 & 22.85 & 62.1 & 12.8 & + & 23.2 & 26.9 & 14.6 & 49.7 & 8.1 & + \\
\hline $\begin{array}{l}\text { Disease } \\
\text { Vascular } \\
\text { Brain }\end{array}$ & 19.5 & 45.9 & 23.7 & 88.9 & 9.13 & + & 15.6 & 35.9 & 15.1 & 85.4 & 5.4 & + \\
\hline Liver cirrhosis & 39.1 & 193.08 & 76.6 & 487.5 & 18.6 & + & 37.5 & 177.1 & 53.3 & 594.2 & 13.3 & + \\
\hline Neoplasms (cancer) & 16.2 & 16.8 & 10.4 & 26.3 & 7.2 & + & 23 & 23.7 & 13.3 & 42.3 & 7.8 & + \\
\hline
\end{tabular}

Table 12: Table of contingency, degree of Association and statistical significance.

\section{Discussion}

IMSS staff presents a frequency of risk factors causing damage to her health similar to the population open to the extent that it resembles their level of schooling, designated by his category work in personnel administration, compared with nurses and medical staff. This situation arises both in sedentary lifestyle, bad eating habits and very prominent in the consumption of legal drugs tobacco and alcohol. Sedentary lifestyle in this study was identified by a criterion of physical exercise moderate to severe for 30 minutes or most days of the week, so its prevalence was above $90 \%$ with greater involvement of women in general. There is an area of important opportunity because in the clinic is perceived which is considered not sedentary people who performed hiking to move or during their daily activities under this heading. To get the benefit for the health of the physical exercise it is required for a minimum time of 20 minutes and to achieve changes in heart rate with increase of $80 \%$ of the maximum heart rate for age. This generates increased due to the increase in mitochondrial oxygen consumption in muscles, increase of glucose transporters, increase the sensitivity of receptors to insulin, decrease blood pressure, endorphins increase, decrease of hepatic fat and decrease in visceral fat in general [29] the bad habits of power in this study were identified by the frequency of 4 to 7 days a week of food consumption with excess calories: tamales, atoles, capeados, breaded, and fried. Fast foods: hot dog, pizza, chicken style kentoky. Scrap: chips, cakes, biscuits, instant soups, soft drinks. Sweet bread 2 and more servings a day. More than 5 a day, 2 and more tablespoons of sugar a day. Add salt to your food to consume them. Not eat vegetables every day. Not eat fruit every day. Not make 3 meals every day, be fasting, only dinner. These everyday habits cause metabolic changes that translate into response Glycemic with abrupt rise of the glucose derived from the consumption of sugar refined with leap of the insulin response with proportional oscillations to the glycemic index of foods high glycemic index all the identified here, (its consumption is an undesirable habit of power.) who are studying with high levels of insulin, which in turn increase the risk of cardiovascular disease and characterized metabolic syndrome by: elevation of insulin, overweight, obesity, lifting of $100 \mathrm{mg} / \mathrm{dl}$ fasting glucose or higher, postprandial of $140 \mathrm{mg} / \mathrm{dl}$ or higher, elevation of blood pressure of $130 / 85$ or greater, triglycerides of $150 \mathrm{mg} / \mathrm{dl}$ or higher, uric acid $5 \mathrm{mg} / \mathrm{dl}$ or greater, waist $80 \mathrm{~cm}$ and $90 \mathrm{~cm}$ in men or older women. Decrease of less than 40 high- density lipoprotein cholesterol $\mathrm{mg} / \mathrm{dl}$ in men of $50 \mathrm{mg} / \mathrm{dl}$ in women [3] respect of the habit of not consuming vegetables and fruit, has been included as a risk factor for the presence of type 2 diabetes mellitus in an index of risk for early identification of pre-diabetes published by Dr. Tuomilehto J in 2002. In this study is clearly associated to obesity in men and women. It is based on adding a point of increased risk of diabetes who not integrated into your daily diet vegetables and fruits, rich in antioxidants, vitamins, enzymes and other nutrients that promote balance Endocrine-Metabolic [30] quartermaster staff presents the higher frequencies in the consumption of unhealthy food and lack of consumption of vegetables and fruit with 10 percentage points higher than the average value, both in men and in women. This is related to their increased frequency of obesity compared with health workers. In our study analyzed the Association of cigarette smoking at least a day associated with depression 3-4 times in men and women respectively. Women also associated with the presence of myocardial infarction 4 times more and 3 times more cerebral vascular disease, compared with women non-smokers, this suggests greater sensitivity to vascular damage generated by at least one smoking a day for women to compare this result in men smokers in this study. In the smokers of more than five cigarettes a day, was associated to obesity, twice in both sexes and was statistically significant. Studies have been conducted to identify the brain areas involved in addiction, the effect is shared in certain food addiction and nicotine [31] the smoking was associated clearly greater than 5 cigarettes a day with hypertension, diabetes mellitus, depression, cardiac infarct, cerebral vascular disease, was statistically significant in both sexes, with greater strength in men; except with chronic obstructive pulmonary disease, which was associated with greater strength in women. When comparing workers with obesity, more nicotine addiction doubles the risk of developing hypertension, diabetes and its complications in terminal damage to organs with greater impact on women, highlighting the presence of cerebral vascular disease followed by cardiac infarct in obese women smokers. Neoplasms are associated in women smokers more 5 cigarettes a day; not so in obese non-smokers. With this result the most damage to health with respect to the dose of nicotine (and other components of the cigar) consumed per day, and which reveal the series of alterations physiopathological which have been linked to the consumption of cigarettes with more than 4 thousand substances including nicotine, including more than 
40 factors and carbon monoxide is evident, by different mechanisms generate hypertension, diabetes, Dyslipidemia, (metabolic syndrome) vascular, pulmonary, liver damage and cancer [32].

Risk (CAR) alcohol and behavior of consumption with varying degrees of addiction, until syndrome withdrawal alcoholic uncomplicated (SDA) (syndrome of severe deprivation and seizures)

The CAR was $40 \%$ in men and $12 \%$ in women; again the quartermaster staff presents the prevalence but high, $45.8 \%$ in men and $21.0 \%$ for females. With respect to conduct of alcohol dependence, the increased frequency was 1: drink more alcohol then planned initially, $26.5 \%$ men and $17.4 \%$ women. Highlights the higher frequency among medical 12.9 doctors $9.0 \% \%$, was also higher in unit 3, 4 and SDA. This result alerts us to apply these questions as part of early detection first consumption of alcohol risk and subsequently tolerance until 1-4 dependence on men and women and identify the behaviors of different degree of alcohol addiction, and promptly inform them about the medium-term risk and accumulated daily alcohol consumption for "acute" damage associated with high mortality and morbidity as the EVC and infarction heart, with irreversible consequences such as liver and vascular complications associated with metabolic syndrome and liver damage by periodic abusive consumption of alcohol [32]. With regard to the Association of obesity - metabolic syndrome with CAR; it arose only in men. There was no association with obesity in women who consume alcohol. Note that in the causation of obesity in men alcohol use plays an important role, by comparing it with the presence of obesity in women who consume unhealthy food and other inadequate habits in your daily diet as they are fasting presented 6 times more in obese women. The probability of depression was statistically significant in both men and women affected by alcohol consumption risk, with greater strength in women. Is alert to female staff who have CAR, because alcohol addiction associated with the presence of the myocardial infarction in women, diabetes and high blood pressure, this suggests damage specific periodic daily alcohol consumption to alter the production of hormones such as catecholamines, steroids with pancreatic dysfunction in the production of insulin and presence of diabetic status. We highlight the most cardiovascular damage in women and neoplasms in males, their physiopathological mechanisms have been associated with the elevation of catecholamines, hypertension and massive production of oxidants, they begin the degenerative cellular damage included the breast cancer in women and prostate in men to be most frequent in the Mexican population [33].

The frequency of registration of chronic disease and its complications was higher in men. We believe that this may be ultimately to greater involvement of men by the consumption of legal drugs alcohol and tobacco, $38 \%-11 \%$ in women for alcohol and 26 against $12 \%$ for women with regard to tobacco, this situation is the best evidence that the vascular complications of metabolic syndrome can be initiated and precipitated by the consumption of tobacco and alcohol. Here it should be noted affecting risk factors most frequently quartermaster personnel. That should alert physicians of promotion and prevention of health to intervene with education to eat healthy foods, exercise and give timely attention of addictions with priority from the open population, as its future health Outlook is not encouraging.

\section{Conclusions}

The likelihood of obesity, chronic diseases and complications was statistically significant in both men and women affected by unhealthy eating habits, sedentary lifestyle and consumption of legal drugs tobacco and alcohol. . In general, the strength of Association of these risk factors with obesity was higher in women this is absolutely indispensable to promote a Decalogue of healthy eating habits for the entire population, practice of daily physical exercise and enjoy your life without drugs.

1. Do 3 meals a day and if it is possible in addition 2 snacks of fruit/vegetable.

2. Drink 3 glasses of cool water or fruits without sugar, in addition to vegetable soups.

3. Include vegetables and fruit at all times

4. Consummated on the 3 main meals: meat of chicken or fish, or pork, or beef, or seafood or veal, eat 2 pieces of bread or 2 integral tortillas a day, made with cooked whole grains

5. 3 times a week 2 whole eggs

6. Eat 3 times per week nuts or peanuts or almonds

7. Do not eat food in via public

8. Does not consume soft drinks, or Light soft drinks, cookies, snacks, fried, sweet biscuits, if you are overweight: don't eat tortillas or bread, do not add sugar or salt.

9. Carried out in 4 to 7 days a week 30 minutes of moderate to intense physical exercise: jogging, aerobics, weightlifting, pilates, spinning, dancing.

10. Stop smoking and seek the help of urgent when it is greater than 5 cigarette consumption per day. Suspend risk alcohol consumption (placed in a visible sign that is risk alcohol consumption and upon affirmative answer any of the questions associated with tolerance or dependence, seek help in a group AA if you have any degree of alcohol addiction).

\section{References}

1. Isomaa B, Almgren P, Tuomi T, Forsén B, Lahti K, et al. (2001) Cardiovascular morbidity and mortality associated with the metabolic syndrome. Diabetes Care 24: 683-689.

2. Lakka HM, Laaksonen DE, Lakka TA, Niskanen LK, Kumpusalo E, et al. (2002) The metabolic syndrome and total and cardiovascular disease mortality in middle-aged men. JAMA 288: 2709-2716.

3. Grundy SM, Cleeman JI, Merz CN, Brewer HB Jr, Clark LT, et al. (2004) Implications of recent clinical trials for the National Cholesterol Education Program Adult Treatment Panel III guidelines. Circulation 110: 227-239.

4. Katzmarzyk PT, Church TS, Janssen I, Ross R, Blair SN (2005) Metabolic syndrome, obesity, and mortality: impact of cardiorespiratory fitness. Diabetes Care 28: 391-397.

5. Fan AZ, Russell M, Naimi T, Li Y, Liao Y, et al. (2008) Patterns of alcohol consumption and the metabolic syndrome. J Clin Endocrinol Metab 93: 38333838.

6. Bijnen FC, Caspersen CJ, Mosterd WL (1994) Physical inactivity as a risk facto for coronary heart disease: a WHO and International Society and Federation of Cardiology position statement. Bull World Health Organ 72: 1-4.

7. Global status report on noncommunicable disaeses 2010 . Geneva, World Health Organization.

8. Global atlas on cardiovascular disease prevention and control. Geneva, World Health Organization, 2011

9. Mathers CD, Loncar D (2006) Projections of global mortality and burden of disease from 2002 to 2030. PLoS Med 3: e442.

10. Lim SS, Vos T, Flaxman AD, Danaei G, Shibuya K, et al. (2012) A comparative risk assessment of burden of disease and injury attributable to 67 risk factors and risk factor clusters in 21 regions, 1990-2010: a systematic analysis for the Global Burden of Disease Study 2010. Lancet 380: 2224-2260.

11. The global burden of disease: 2004 update. Geneva, World Health Organization 2008

12. Rehm J and colab. (2002) Alcohol as a Risk Factor for Burden of Disease. World Health Organization. 
Citation: Velasco-Contreras Grado ME (2014) Does Smoking and Alcohol Abuse Precipitate and Aggravate the Risk of Metabolic Syndrome? J Metabolic Synd 3: 141. doi:10.4172/2167-0943.1000141

Page 12 of 12

13. Schrauwen-Hinderling VB1, Hesselink MK, Meex R, van der Made S, Schär $M$, et al. (2010) Improved ejection fraction after exercise training in obesity is accompanied by reduced cardiac lipid content. J Clin Endocrinol Metab 95: 1932-1938.

14. Tuomilehto J, Lindström J, Eriksson JG, Valle TT, Hämäläinen $\mathrm{H}$, et al. (2001) Prevention of type 2 diabetes mellitus by changes in lifestyle among subjects with impaired glucose tolerance. N Engl J Med 344: 1343-1350.

15. Tobacco free initiative (2006) World Health organization. Geneva.

16. Neuroscience of psychoactive substance use and dependence (2004) ISBN 92 4156235 8. World Health Organization.

17. National survey of 2007 addiction (ENA/2007)

18. Ministry of health, General Directorate of epidemiology, National Institute of Psychiatry. National addictions survey. Tobacco. Mexico DF: SSA, 2008

19. Rehm J and colab (2002) alcohol as a risk factor for burden of disease. World Health Organization.

20. Alcoholism. Scientific evidence-based clinical guidelines: Socidroga-alcoho 2008,(2rdedn)

21. Standard Oficial Mexicana NOM-174-SSA1-1998, for the comprehensive management of obesity. México D.F. 2000

22. Haffner SM, Mykkänen L, Festa A, Burke JP, Stern MP (2000) Insulin-resistant prediabetic subjects have more atherogenic risk factors than insulin-sensitive prediabetic subjects: implications for preventing coronary heart disease during the prediabetic state. Circulation 101: 975-980.

23. Bonora E, Kiechl S, Willeit J, Oberhollenzer F, Egger G, et al. (1998) Prevalence of insulin resistance in metabolic disorders: the Bruneck Study. Diabetes 47: 1643-1649.

24. Dandona P, Aljada A, Chaudhuri A, Mohanty P, Garg R (2005) Metabolic syndrome: a comprehensive perspective based on interactions between obesity, diabetes, and inflammation. Circulation 111: 1448-1454.

25. Sonnenberg GE, Krakower GR, Kissebah AH (2004) A novel pathway to the manifestations of metabolic syndrome. Obes Res 12: 180-186.

26. Jennie C Brand-Miller Karola, Stockman, Fiona Atkinson, Peter Petocs, et al. (2009) Glycemic index, postprandial glycemia, and the shape of the curve in healthy subjets: analysis of a database of more than 1000 foods. Am j Clin Nutr 89: 97-105

27. Tuomilehto J, Lindström J, Eriksson JG, Valle TT, Hämäläinen H, et al. (2001) Prevention of type 2 diabetes mellitus by changes in lifestyle among subjects with impaired glucose tolerance. N Engl J Med 344: 1343-1350.

28. The practical guide to the identification, evaluation and treatment of overweight and obesity in adults (2000) NHLBI Obesity Education Initiative.

29. Schrauwen-Hinderling VB, Hesselink MK, Meex R, van der Made S, Schär $M$, et al. (2010) Improved ejection fraction after exercise training in obesity is accompanied by reduced cardiac lipid content. J Clin Endocrinol Metab 95: 1932-1938.

30. Tuomilehto J, Lindström J, Eriksson JG, Valle TT, Hämäläinen H, et al. (2001) Prevention of type 2 diabetes mellitus by changes in lifestyle among subjects with impaired glucose tolerance. N Engl J Med 344: 1343-1350.

31. Neuroscience of Psychoactive Substance Use and Dependence (2004). ISBN 9241562358 World Health Organization.

32. Lim SS, Vos T, Flaxman AD, Danaei G, Shibuya K, et al. (2012) A comparative risk assessment of burden of disease and injury attributable to 67 risk factors and risk factor clusters in 21 regions, 1990-2010: a systematic analysis for the Global Burden of Disease Study 2010. Lancet 380: 2224-2260.

33. Aalto M, Pekuri P, Seppä K (2001) Primary health care nurses' and physicians' attitudes, knowledge and beliefs regarding brief intervention for heavy drinkers. Addiction 96: 305-311 